\title{
PENGARUH TATA KELOLA PERUSAHAAN TERHADAP NILAI PERUSAHAAN PADA PERUSAHAAN SUB SEKTOR FARMASI YANG TERDAFTAR DI BURSA EFEK INDONESIA
}

\author{
Oleh : \\ Pina Anggi Yunita \\ S1 Akuntansi \\ Liper Siregar, Jubi, Astuti
}

Abstrak

Penelitian ini bertujuan untuk: 1. Mengetahui Gambaran Tata Kelola Perusahaan dan Nilai Perusahaan Pada Perusahaan Sub Sektor Farmasi yang Terdaftar di Bursa Efek Indonesia. 2. Mengetahui Pengaruh Tata Kelola Perusahaan Terhadap Nilai Perusahaan Pada Perusahaan Sub Sektor Farmasi yang Terdaftar di Bursa Efek Indonesia baik secara simultan maupun parsial.

Hasil penelitian ini dapat disimpulkan sebagai berikut : 1. Rata-rata tata kelola perusahaan dengan proksi kepemilikan institusional adalah 0,1883 , dewan komisaris independen adalah 0,4150 dan komite audit adalah 0,5333, rata-rata Price to Book Value (PBV) adalah 5,5275. Hasil pengujian dari regresi linier berganda adalah : $\hat{Y}=14,079+8,077 X_{1}-21,117 X_{2}-2,457 X_{3}$, artinya tata kelola perusahaan dengan kepemilikan institusional berpengaruh positif terhadap nilai perusahaan sedangkan dewan komisaris independen dan komite audit berpengaruh negatif terhadap nilai perusahaan. Hasil uji koefisien korelasi sebesar 0,437 yang berarti hubungan sedang antara tata kelola perusahaan terhadap Nilai Perusahaan. Koefisien determinasi (R Square) adalah sebesar 0,191 yang berarti bahwa $19,1 \%$ dari nilai perusahaan dijelaskan oleh Tata Kelola Perusahaan. Hipotesis penelitian $\mathrm{H}_{0}$ diterima, artinya tata kelola perusahaan berpengaruh tidak signifikan terhadap nilai perusahaan Pada Perusahaan Sub Sektor Farmasi yang terdaftar di Bursa Efek Indonesia baik secara simultan maupun parsial.

Kata Kunci : Tata Kelola Perusahaan, Kepemilikan Institusional, Dewan Komisaris Independen, Komite Audit, Nilai Perusahaan

Abstract

The purpose of this research are1. To know the description of Good Corporate Governance and Firm Value in the subsector company of pharmacy listed in Indonesia Stock Exchange And 2. To know the influence of Good Corporate Governance to Firm Value in the subsector company of pharmacy listed in Indonesia Stock Exchange.

The result of the research are 1. The average of good corporate governance with indicator Institutional ownership is 0,1883, Independent Commissioner is 0,4150 and Audit Committe is 0,5333 and average of Price to Book Value (PBV) is 5,5275. 2. The result of multiple regression linier is $\hat{Y}=$ $14,079+8,077 X_{1}-21,117 X_{2}-2,457 X_{3}$. Which means there is positive correlation between good corporate governance used indicator Institutional ownership with firm value and negative correlation Independent Commissioner and Audit Committe with firm value. 3. The coefficient of correlation is 0,437, which means there is medium correlation between independent variables with dependent variabel. The coefficient of determination is 0,191 , which means $19,1 \%$ of firm value is explained by good corporate governance. 4. Research hypothesis $H_{0}$ is accepted, which means good corporate governance have no significant effect on firm value in the subsector company of pharmacy which listed in Indonesia Stock Exchange either partially or simultaneously.

Keyword : Good Corporate Governance, Institutional ownership, Independent Commissioner, Audit Committe, Firm Value.

\section{A. PENDAHULUAN}

\section{Latar Belakang Masalah}

Tujuan didirikannya suatu perusahaan umumnya adalah untuk memaksimumkan nilai perusahaan. Nilai perusahaan yang tinggi akan membuat investor tertarik untuk berinvestasi pada perusahaan tersebut. Memaksimalkan nilai perusahaan sangat penting bagi suatu perusahaan. Karena hal ini dapat meningkatkan kemakmuran pemilik dan para pemegang saham sehingga tujuan perusahaan dapat tercapai sesuai dengan yang diharapkan.

Penerapan tata kelola perusahaan (good corporate governance) memiliki peran penting dalam meningkatkan kesejahteraan para pemilik dan memaksimalkan kekayaan pemegang saham memalui peningkatan nilai perusahaan. 
Tabel 1

Gambaran Rata-rata Price to Book Value (PBV) Pada Perusahaan Sub Sektor Farmasi yang Terdaftar di Bursa Efek Indonesia Periode 2012-2016

\begin{tabular}{|c|c|c|c|c|c|c|c|}
\hline $\begin{array}{c}\text { Kode } \\
\text { Emiten }\end{array}$ & \begin{tabular}{|l|} 
Nama \\
Perusahaan
\end{tabular} & $\begin{array}{c}2012 \\
\text { (kali) }\end{array}$ & $\begin{array}{l}2013 \\
\text { (kali) }\end{array}$ & $\begin{array}{l}2014 \\
\text { (kali) }\end{array}$ & $\begin{array}{l}2015 \\
\text { (kali) }\end{array}$ & $\begin{array}{l}2016 \\
\text { (kali) }\end{array}$ & $\begin{array}{l}\text { Rata-rata } \\
\text { erusahaan } \\
\text { (kali) }\end{array}$ \\
\hline INAF & $\begin{array}{l}\text { PT } \\
\text { Indofarma, } \\
\text { Tbk }\end{array}$ & 2,2893 & 223 & 8312 & 0,8786 & $e 5,194$ & 6,4835 \\
\hline KAEF & $\begin{array}{l}\text { PT Kimia } \\
\text { Farma } \\
\text { (Persero), } \\
\text { Tbk }\end{array}$ & 2,803 & 1,9996 & 64,3939 & 2,3526 & 6,694 & 3,6486 \\
\hline KLBF & \begin{tabular}{|l|} 
PT Kalbe \\
Farma, Tbk
\end{tabular} & 6,8622 & 7,265 & 9,1916 & $\phi, 925$ & tᄒ,976丸 & 7,0442 \\
\hline MERK & $\begin{array}{l}\text { PT Merck } \\
\text { Indonesia, } \\
\text { Tbk }\end{array}$ & 8,170 & 8,265 & $0,472 \$$ & $\$, 4096$ & $67,073 \oint$ & 7,2783 \\
\hline TSPC & $\begin{array}{l}\text { PT Tempo } \\
\text { Scan } \\
\text { Pasific, Tbk }\end{array}$ & 4,9954 & 3,874 & 3,2064 & 41,872 & 1,966 & 3,1829 \\
\hline Rata-rat & $\begin{array}{l}\text { a per Tahun } \\
\text { (kali) }\end{array}$ & 5,024 & $4,525 ?$ & $\bar{b}, 2193$ & 3,4877 & 9,3810 & $\$ 5275$ \\
\hline
\end{tabular}

Dari Tabel 1 dapat dilihat bahwa rata-rata PBV pada Perusahaan Sub Sektor Farmasi yang terdaftar di Bursa Efek Indonesia periode 2012-2016 mengalami fluktuasi setiap tahunnya namun cenderung meningkat. Nilai rata-rata PBV keseluruhan adalah sebesar 5,5275, yang artinya harga pasar saham perusahaan dinilai lebih tinggi dari nilai bukunya. Price to Book Value (PBV) mengindikasikan nilai perusahaan. Semakin besar rasio PBV semakin tinggi perusahaan dinilai oleh para pemodal relatif dibanding dengan dana yang ditanamkan di perusahaan.

Menurut Hamdani (2016:129), semakin tinggi penerapan tata kelola perusahaan maka akan meningkatkan nilai perusahaan. Tata kelola perusahaan dalam penelitian ini menggunakan proksi kepemilikan institusional, dewan komisaris independen dan komite audit.

\section{Rumusan Masalah}

a. Bagaimana gambaran tata kelola perusahaan dan nilai perusahaan pada Perusahaan Sub Sektor Farmasi yang terdaftar di Bursa Efek Indonesia..

b. Bagaimana pengaruh tata kelola perusahaan terhadap nilai perusahaan pada Perusahaan Sub Sektor Farmasi yang terdaftar di Bursa Efek Indonesia baik secara simultan maupun parsial.

\section{Tujuan Penelitian}

a. Untuk mengetahui gambaran tata kelola perusahaan dan nilai perusahaan pada Perusahaan Sub Sektor Farmasi yang terdaftar di Bursa Efek Indonesia

b. Untuk mengetahui pengaruh tata kelola perusahaan terhadap nilai perusahaan pada Perusahaan Sub Sektor Farmasi yang terdaftar di Bursa Efek Indonesia baik secara simultan maupun parsial.

\section{Metodologi Penelitian}

Objek penelitian Perusahaan Sub Sektor Farmasi yang terdaftar di Bursa Efek Indonesia. Penelitian ini dilakukan dengan menggunakan data skunder, untuk mendapatkan data informasi yang dibutuhkan dalam penelitian ini, maka dilakukan dengan cara mengakses dari situs http://www.idx.co.id

Desain penelitian yang digunakan dalam penelitian ini adalah penelitian kepustakaan (library research). Teknik analisa data yang digunakan dalam penelitian ini adalah Uji Asumsi Klasik, Analisa Deskriptif Kualitatif, Analisa Deskriptif Kuantitatif

\section{B. LANDASAN TEORI}

\section{Laporan Keuangan}

Menurut Kasmir (2010:66), secara umum menyatakan bahwa laporan keuangan adalah laporan yang menunjukkan kondisi keuangan perusahaan pada saat ini atau pada periode tertentu. Laporan keuangan juga menunjukkan apa yang telah dilakukan manajemen atau pertanggungjawaban manajemen atas sumber daya yang dipercayakan kepadanya. Menurut Astuti (2012:37), laporan keuangan adalah output dari proses akuntansi yang berguna bagi pihak-pihak yang berkepentingan

menurut Kasmir (2010:86), tujuan laporan keuangan adalah untuk memberikan informasi keuangan suatu perusahaan, baik pada saat/periode tertentu dan dapat disusun secara mendadak untuk kebutuhan perusahaan maupun secara berkala. Baridwan (2008:3), menyatakan bahwa tujuan laporan keuangan menurut.

\section{Teori Keagenan}

Menurut Hamdani (2016:30), dalam teori keagenan dijelaskan bahwa hubungan keagenan adalah sebuah kontrak antara manajer (agent) dengan investor (principal). Konflik kepentingan antara pemilik dan agen terjadi karena kemungkinan agen tidak selalu berbuat sesuai dengan kepentingan principal.

Menurut Jensen dan Meckling dalam Sutedi (2011:17), Agency theory adalah sebuah kontrak antara satu orang atau lebih (principals) bekerja sama dengan orang lain (agent) untuk melaksanakan pelayanan atas diri mereka termasuk mendelegasikan otoritas membuat keputusan kepada agen. Bila keduanya bekerjasama untuk suatu hubungan memaksimalkan utilitas maka sebuah alasan bagus untuk mempercayai bahwa agen tidak selalu bersikap sesuai dengan keinginan prinsipal. 


\section{Tata Kelola Perusahaan}

Menurut Sutedi (2011:7), good corporate governance adalah seperangkat peraturan yang mengatur hubungan antara pemegang saham, pengurus (pengelola) perusahaan, pihak kreditur, pemerintah, karyawan serta para pemegang kepentingan internal dan eksterna lainnya yang berkaitan dengan hak-hak dan kewajiban mereka atau dengan kata lain suatu sistem yang mengatur dan mengendalikan perusahaan.

Pada penelitian ini, penulis hanya menggunakan kepemilikan institusional, dewan komisaris independen dan komite audit sebagai parameter tata kelola perusahaan. Kepemilikan institusional diperoleh dengan membandingkan saham yang dimiliki instutisi lain dalam perusahaan dengan jumlah saham yang beredar, dewan komisaris independen diperoleh dengan membandingkan komisaris independen dengan jumlah seluruh dewan komisaris sedangkan komite audit diperoleh dengan membandingkan komite audit yang berasal dari luar emiten atau perusahaan publik dengan jumlah seluruh komite audit

Faktor-faktor yang mempengaruhi tata kelola perusahaan tersebut antara lain:

a. Faktor Eksternal

Faktor eksternal adalah beberapa faktor yang berasal dari luar perusahaan yang sangat mempengaruhi keberhasilan penerapan GCG, di antaranya:

1) Terdapatnya sistem hukum yang baik sehingga mampu menjamin berlakunya supremasi hukum yang konsisten dan efektif.

2) Dukungan pelaksanaan GCG dari sektor publik/lembaga pemerintahaan yang diharapkan dapat pula melaksanakan Good

Governance dan Clean

Government menuju Good Government Governance yang sebenarnya.

3) Terdapatnya contoh pelaksanaan GCG yang tepat (best practices) yang dapat menjadi standar pelaksanaan GCG yang efektif dan profesional. Dengan kata lain, semacam benchmark (acuan).

4) Terbangunnya sistem tata nilai sosial yang mendukung penerapan GCG di masyarakat. Ini penting karena lewat sistem ini diharapkan timbul partisipasi aktif berbagai kalangan masyarakat untuk mendukung aplikasi serta sosialisasi GCG secara sukarela.

5) Hal lain yang tidak kalah pentingnya sebagai prasyarat keberhasilan implementasi GCG terutama di Indonesia adalah adanya semangat anti korupsi yang berkembang di lingkungan publik di mana perusahaan beroperasi disertai perbaikan masalah kualitas pendidikan dan perluasan peluang kerja. Bahkan dapat dikatakan bahwa perbaikan lingkungan publik sangat mempengaruhi kualitas dan skor perusahaan dalam implementasi GCG.

b. Faktor Internal

Faktor internal adalah pendorong keberhasilan pelaksanaan praktik GCG yang berasal dari dalam perusahaan. Beberapa faktor yang dimaksud antara lain:

1) Terdapatnya budaya perusahaan (corporate culture) yang mendukung penerapan GCG dalam mekanisme serta sistem kerja manajemen di perusahaan.

2) Berbagai peraturan dan kebijakan yang dikeluarkan perusahaan mengacu pada penerapan nilai-nilai GCG.

3) Manajemen pengendalian risiko perusahaan juga didasarkan pada kaidah-kaidah standar GCG.

4) Terdapatnya sistem audit (pemeriksaan) yang efektif dalam perusahaan untuk menghindari setiap penyimpangan yang mungkin akan terjadi.

5) Adanya keterbukaan informasi bagi publik untuk mampu memahami setiap gerak dan langkah manajemen dalam perusahaan sehingga kalangan publik dapat memahami dan mengikuti setiap derap langkah perkembangan dan dinamika perusahaan dari waktu ke waktu.

\section{Nilai Perusahaan}

Menurut Keown (2004:470), nilai perusahaan adalah nilai pasar atas surat berharga hutang dan ekuitas perusahaan yang beredar.

Menurut Horne dan John (2012:3), faktorfaktor yang mempengaruhi nilai perusahaan adalah:

a. Keputusan Investasi

b. Keputusan Pendanaan

c. Keputusan Manajemen Aset

\section{Pengaruh Tata Kelola Perusahaan} terhadap Nilai Perusahaan

Mekanisme tata kelola yang baik (good corporate governance) yang dilandasi prinsip corporate governance ini diharapkan dapat mengurangi masalah keagenan dalam perusahaan. Perusahaan yang dapat mengungkapkan informasi lebih banyak terkait dengan aspek keuangan, aspek hukum dan manajemen kepada pihak lain, akan memberikan sinyal positif kepada pasar sehingga para pelaku pasar bersedia membeli saham perusahaan lebih banyak. Semakin banyak permintaan terhadap saham perusahaan, maka semakin tinggi nilai perusahaan. Semakin tinggi penerapan tata 
kelola perusahaan maka akan meningkatkan nilai perusahaan (Hamdani, 2016:129)

\section{PEMBAHASAN}

1. Analisis

a. Analisis Deskripsi Kualitatif

1) Gambaran Kepemilikan Institusional Pada Perusahaan Sub Sektor Farmasi yang terdaftar di Bursa Efek Indonesia periode 2012-2016

Rata-rata Kepemilikan Institusional Pada Perusahaan Sub Sektor Farmasi yang terdaftar di Bursa Efek Indonesia periode 2012-2016 pada Tabel 2.

Tabel 2

Rata-rata Kepemilikan Institusional Pada Perusahaan Sub Sektor Farmasi yang

Terdaftar di Bursa Efek Indonesia Periode 2012-2016

\begin{tabular}{|c|c|c|c|c|c|c|c|}
\hline $\begin{array}{l}\text { Kode } \\
\text { Emiten }\end{array}$ & $\begin{array}{c}\text { Nama } \\
\text { Perusahaan }\end{array}$ & $\begin{array}{l}2012 \\
\text { (kali) }\end{array}$ & $\begin{array}{l}2013 \\
\text { (kali) }\end{array}$ & $\begin{array}{l}2014 \\
\text { (kali) }\end{array}$ & $\begin{array}{l}2015 \\
\text { (kali) }\end{array}$ & $\begin{array}{l}2016 \\
\text { (kali) }\end{array}$ & $\begin{array}{c}\text { Rata-rata } \\
\text { per } \\
\text { Perusahaan } \\
\text { (kali) }\end{array}$ \\
\hline INAF & $\begin{array}{l}\text { PT } \\
\text { Indofarma, } \\
\text { Tbk }\end{array}$ & b,0557 & $p, 0557$ & $\phi, 0556$ & $\mid 0464$ & $D, 1175$ & 0,0662 \\
\hline KAEF & $\begin{array}{l}\text { PT Kimia } \\
\text { Farma } \\
\text { (Persero), } \\
\text { Tbk }\end{array}$ &, 0637 &, 0621 & 370 &, 0624 & $D, 0620$ & 0,0634 \\
\hline KLBF & $\begin{array}{l}\text { PT } \quad \text { Kalbe } \\
\text { Farma, Thk }\end{array}$ & 3951 & & ,3937 & & 3,3800 & 0,3903 \\
\hline MERK & $\begin{array}{l}\text { PT Merck } \\
\text { Indonesia, } \\
\text { Tbk }\end{array}$ & ,2010 & ,203C, & p,2025 & , 1953 & p,1933 & 0,1990 \\
\hline TSPC & $\begin{array}{ll}\text { PT } & \text { Tempo } \\
\text { Scan Pasific, } \\
\text { Tbk }\end{array}$ & , 215 & & 248 & 2266 & $b, 2271$ & 0,2225 \\
\hline \multicolumn{2}{|c|}{$\begin{array}{c}\text { Rata-rata per Tahun } \\
\text { (kali) }\end{array}$} & p,186 & & & & & \\
\hline \multicolumn{7}{|c|}{$\begin{array}{l}\text { Kepemilikan Institusional Minimum } \\
\text { Kepemilikan Institusional Maksimum }\end{array}$} & 0,0464 \\
\hline \multicolumn{7}{|c|}{$\begin{array}{c}\text { Kepemillkan Institusional Maksimum } \\
\text { Rata-rata Kepemilikan Institusional }\end{array}$} & $\begin{array}{l}0,3951 \\
0,1883\end{array}$ \\
\hline
\end{tabular}

Sumber: Data diolah

Dari Tabel 2, dapat disajikan grafik sebagai berikut:

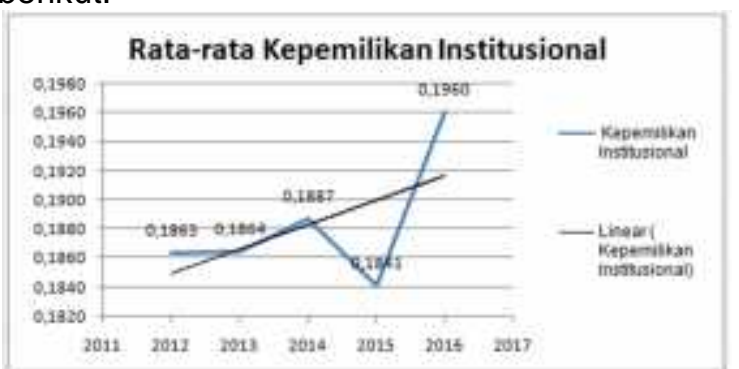

Sumber: Data Diolah

Gambar 1

Grafik Rata-rata Kepemilikan Institusional pada Perusahaan Sub Sektor Farmasi Periode 2012-2016

Berdasarkan Tabel 2 dan Gambar 1 di atas di atas dapat dilihat nilai rata-rata kepemilikan institusional pada Perusahaan Sub Sektor Farmasi periode 2012-2016 berfluktuasi setiap tahunnya namun memiliki kecenderungan meningkat. Hal ini disebabkan perusahaan dalam Sub Sektor Farmasi mengalami peningkatan saham yang dimiliki institusi lain dalam perusahaan.

kepemilikan institusional memiliki nilai rata-rata keseluruhan adalah sebesar 0,1883. Dari nilai rata-rata tersebut mengartikan bahwa jumlah saham yang dimiliki institusi lain dalam perusahaan sebesar $18,83 \%$ dari seluruh jumlah saham yang beredar.

Selain itu dapat dilihat nilai minimum berada pada tahun 2015 yaitu pada PT Indofarma, Tbk sebesar 0,0464. Nilai minimum tersebut menjelaskan bahwa jumlah saham yang dimiliki oleh institusi lain pada PT Indofarma, Tbk sebesar $4,64 \%$ dari seluruh jumlah saham yang beredar pada PT Indofarma, Tbk. Sedangkan nilai maksimum dari kepemilikan institusional sebesar 0,3951 berada pada tahun 2012 pada PT Kalbe Farma, Tbk. Nilai maksimum tersebut menjelaskan bahwa jumlah saham yang dimiliki oleh institusi lain pada PT Kalbe Farma, Tbk sebesar 39,51\% dari seluruh jumlah saham yang beredar.

Dari nilai rata-rata keseluruhan tersebut dapat dilihat ada 3 perusahaan yang memiliki nilai kepemilikan institusional di atas rata-rata antara lain PT Kalbe Farma, Tbk, PT Merck Indonesia, Tbk dan PT Tempo Scan Pasific, Tbk. Sedangkan yang memiliki nilai di bawah rata-rata ada 2 perusahaan antara lain PT Indofarma, Tbk dan PT Kimia Farma (Persero), Tbk.

2) Gambaran Dewan Komisaris Independen Pada Perusahaan Sub Sektor Farmasi yang terdaftar di Bursa Efek Indonesia periode 2012-2016

Rata-rata Dewan Komisaris Independen Pada Perusahaan Sub Sektor Farmasi yang terdaftar di Bursa Efek Indonesia periode 20122016. Sebagai berikut :

Tabel 3

Rata-rata Dewan Komisaris Independen Pada Perusahaan Sub Sektor Farmasi yang Terdaftar di Bursa Efek Indonesia Periode

\begin{tabular}{|c|c|c|c|c|c|c|c|}
\hline & & & & 20 & & & \\
\hline $\begin{array}{c}\text { Kode } \\
\text { Emiten }\end{array}$ & $\begin{array}{c}\text { Nama } \\
\text { Perusahaan }\end{array}$ & $\begin{array}{l}2012 \\
\text { (kali) }\end{array}$ & $\begin{array}{l}2013 \\
\text { (kali) }\end{array}$ & $\begin{array}{l}2014 \\
\text { (kali) }\end{array}$ & $\begin{array}{l}2015 \\
\text { (kali) }\end{array}$ & $\begin{array}{l}2016 \\
\text { (kali) }\end{array}$ & $\begin{array}{c}\text { Rata-rata } \\
\text { per } \\
\begin{array}{c}\text { Perusahaan } \\
\text { (kali) }\end{array} \\
\end{array}$ \\
\hline INAF & $\begin{array}{l}\text { PT } \\
\text { Indofarma, } \\
\text { Tbk }\end{array}$ & 0,5000 & 0,5000 & 0,3333 & $\begin{array}{lll}3 & 0,3333 \\
\end{array}$ & 0,3333 & 0,4000 \\
\hline KAEF & $\begin{array}{l}\text { PT Kimia } \\
\text { Farma } \\
\text { (Persero), } \\
\text { Tbk }\end{array}$ & 0,4000 & 0,4000 & 0,4000 & 0,4000 & 0,4000 & 0,4000 \\
\hline KLBF & \begin{tabular}{|l} 
PT Kalbe \\
Farma, Tbk
\end{tabular} & 0,3333 & 0,3333 & 0,3333 & $\begin{array}{ll}3 & 0,4286 \\
\end{array}$ & 0,4286 & 0,3714 \\
\hline MERK & $\begin{array}{l}\text { PT Merck } \\
\text { Indonesia, } \\
\text { Tbk }\end{array}$ & 0,3333 & 0,3333 & 0,3333 & 3 & 0,3333 & 0,3333 \\
\hline TSPC & $\begin{array}{l}\text { PT Tempo } \\
\text { Scan } \\
\text { Pasific, Tbk }\end{array}$ & 0,5000 & 0,6000 & 0,7500 & 0,5000 & 0,5000 & 0,5700 \\
\hline $\begin{array}{c}\text { Rata- } \\
\text { tahu }\end{array}$ & $\begin{array}{l}\text { i-rata per } \\
\text { un (kali) }\end{array}$ & 0,4133 & 0,4333 & 0,4300 & 0,3990 & 0,3990 & - \\
\hline & Dewan $\mathrm{K}$ & & & $\operatorname{den} 1$ & & & 0,3333 \\
\hline & Dewan K & & & $\frac{\operatorname{len~Mz}}{s \text { Inde }}$ & simu & & $\begin{array}{l}0,7500 \\
0,4150\end{array}$ \\
\hline
\end{tabular}

Sumber: Data diolah 
Berdasarkan Tabel 3 grafik rata-rata dewan komisaris independen pada Perusahaan Sub Sektor Farmasi yang Terdaftar di Bursa Efek Indonesia Periode 2012-2016. sebagai berikut:

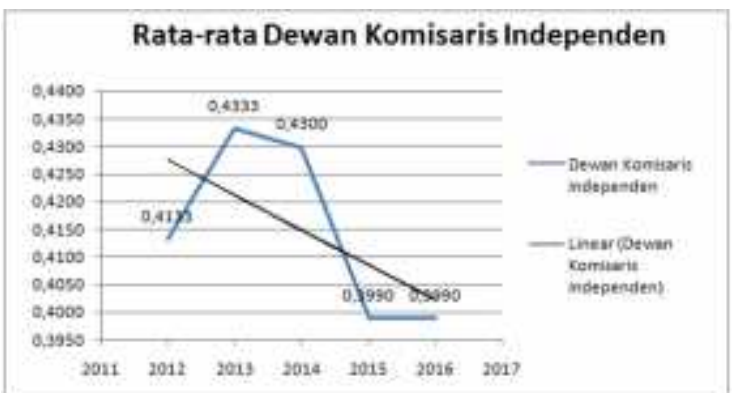

Sumber: Data Diolah

Gambar 2

Grafik Rata-rata Dewan Komisaris Independen pada Perusahaan Sub Sektor Farmasi Periode 2012-2016

Berdasarkan Tabel 3 dan Gambar 2, dapat dilihat nilai rata-rata dewan komisaris independen pada Perusahaan Sub Sektor Farmasi periode 2012-2016 berfluktuasi setiap tahunnya namun memiliki kecenderungan menurun. Hal ini disebabkan jumlah dewan komisaris independen pada Perusahaan Sub Sektor Farmasi mengalami penurunan dibanding dengan jumlah seluruh dewan komisaris. Nilai rata-rata dewan komisaris independen secara keseluruhan adalah sebesar 0,4150 . Dari nilai rata-rata tersebut mengartikan bahwa jumlah komisaris independen yang ada dalam perusahaan sebesar $41,25 \%$ dari seluruh jumlah dewan komisaris.

Selain itu dapat dilihat nilai minimum berada pada beberapa perusahaan yaitu PT Kalbe Farma, Tbk tahun 2012-2014, PT Merck Indonesia, Tbk tahun 2012-2016, dan PT Indofarma, Tbk tahun 2014-2016 yaitu sebesar 0,3333 . Nilai minimum tersebut menjelaskan bahwa jumlah dewan komisaris independen pada PT Kalbe Farma, Tbk tahun 2012-2014, PT Merck Indonesia, Tbk tahun 2012-2016, dan PT Indofarma, Tbk tahun 2014-2016 adalah sebesar $33,33 \%$ dari seluruh jumlah dewan komisaris. Sedangkan nilai maksimum dari dewan komisaris independen sebesar 0,7500 berada pada tahun 2014 pada PT Tempo Scan Pasific, Tbk. Nilai maksimum tersebut menjelaskan bahwa jumlah dewan komisaris independen pada PT Tempo Scan Pasific, Tbk sebesar $75 \%$ dari seluruh jumlah dewan komisaris.

Dari nilai rata-rata keseluruhan dapat dilihat pada Tabel 3 ada 1 perusahaan yang memiliki nilai dewan komisaris independen di atas rata-rata yaitu PT Tempo Scan Pasific, Tbk, sedangkan yang memiliki nilai di bawah rata-rata ada 4 perusahaan antara lain PT Kalbe Farma, Tbk, PT Merck Indonesia, Tbk,
PT Indofarma, Tbk dan PT Kimia Farma (Persero), Tbk.

3) Gambaran Komite Audit Independen Pada Perusahaan Sub Sektor Farmasi yang terdaftar di Bursa Efek Indonesia periode 2012-2016

Rata-rata Komite Audit Independen Pada Perusahaan Sub Sektor Farmasi yang terdaftar di Bursa Efek Indonesia periode 2012-2016. Sebagai berikut :

Tabel 4

Rata-rata Komite Audit Independen Pada

Perusahaan Sub Sektor Farmasi yang Terdaftar di Bursa Efek Indonesia Periode 2012-2016

\begin{tabular}{|c|c|c|c|c|c|c|c|}
\hline $\begin{array}{c}\text { Kode } \\
\text { Emiten }\end{array}$ & $\begin{array}{c}\text { Nama } \\
\text { Perusahaan }\end{array}$ & $\begin{array}{l}2012 \\
\text { (kali) }\end{array}$ & $\begin{array}{l}2013 \\
\text { (kali) }\end{array}$ & $\begin{array}{l}2014 \\
\text { (kali) }\end{array}$ & $\begin{array}{l}2015 \\
\text { (kali) }\end{array}$ & $\begin{array}{l}2016 \\
\text { (kali) }\end{array}$ & \begin{tabular}{|c|} 
Rata-rata \\
per \\
Perusahaan \\
(kali)
\end{tabular} \\
\hline INAF & $\begin{array}{l}\text { PT } \\
\text { Indofarma, } \\
\text { Tbk }\end{array}$ & 0,5000 & 0,5000 & 0,3333 & 0,5000 & 0,5000 & 0,4667 \\
\hline KAEF & \begin{tabular}{|l} 
PT Kimia \\
Farma \\
(Persero), \\
Tbk
\end{tabular} & $\mid 0,6667$ & $\mid 0,6667$ & $\mid 0,6667$ & $\mid 0,6667$ & 0,6667 & 0,6667 \\
\hline KLBF & $\begin{array}{l}\text { PT Kalbe } \\
\text { Farma, Tbk }\end{array}$ & 0,6667 & 0,6667 & 0,6667 & 0,6667 & 0,6667 & 0,6667 \\
\hline MERK & $\begin{array}{l}\text { PT Merck } \\
\text { Indonesia, } \\
\text { Tbk }\end{array}$ & 0,6667 & 0,6667 & $\mid 0,6667$ & $0,6667 \mid$ & 0,6667 & 0,6667 \\
\hline TSPC & $\begin{array}{l}\text { PT Tempo } \\
\text { Scan Pasific, } \\
\text { Tbk }\end{array}$ & $\mid 0,6667$ & 0 & 0 & 0,3333 & 0 & 0,2000 \\
\hline $\begin{array}{r}\text { Rate } \\
\text { tah }\end{array}$ & $\begin{array}{l}\text { a-rata per } \\
\text { un (kali) }\end{array}$ & 0,6333 & 0,5000 & 0,4667 & 0,5667 & 0,5000 & - \\
\hline \multicolumn{7}{|c|}{ Komite Audit Minimum } & 0 \\
\hline \multicolumn{7}{|c|}{ Komite Audit Maksimum } & 0,6667 \\
\hline \multicolumn{7}{|c|}{ Rata-rata Komite Audit } & 0,5333 \\
\hline
\end{tabular}

Sumber: Data Diolah

Berdasarkan Tabel 3 grafik rata-rata komite audit independen pada Perusahaan Sub Sektor Farmasi yang Terdaftar di Bursa Efek Indonesia Periode 2012-2016. sebagai berikut:

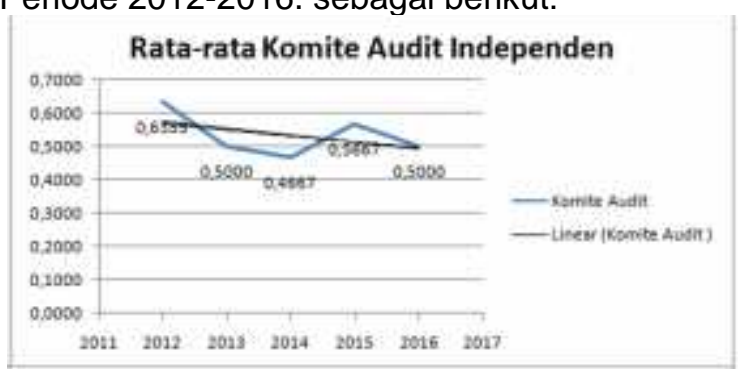

Sumber: Data Diolah

Gambar 3

Grafik Rata-rata Komite Audit Independen pada Perusahaan Sub Sektor Farmasi Periode 2012-2016

Berdasarkan Tabel 3 dan Gambar 2, dapat dilihat nilai rata-rata komite audit independen pada Perusahaan Sub Sektor Farmasi periode 2012-2016 berfluktuasi setiap tahunnya namun memiliki kecenderungan menurun. Hal ini disebabkan jumlah komite audit independen pada Perusahaan Sub Sektor 
Farmasi mengalami penurunan atau lebih kecil dibanding dengan jumlah seluruh komite audit.

Berdasarkan Tabel 4 dapat dilihat bahwa nilai rata-rata komite audit secara keseluruhan adalah sebesar 0,5333. Dari nilai rata-rata tersebut mengartikan bahwa jumlah komite audit independen yang ada dalam perusahaan sebesar $53,33 \%$ dari seluruh jumlah komite Audit.

Selain itu dapat dilihat nilai minimum berada pada PT Tempo Scan Pasific, Tbk tahun 2013, 2014 dan 2016 sebesar 0. Nilai minimum menjelaskan bahwa tidak terdapat komite audit independen pada PT Tempo Scan Pasific, Tbk tahun 2013,2014 dan 2016. Sedangkan nilai maksimum dari komite audit sebesar 0,6667 berada pada setiap tahun penelitian untuk PT Kimia Farma (Persero), Tbk, PT Kalbe Farma Tbk, PT Merck Indonesia, Tbk dan hanya tahun 2012 untuk PT Tempo Scan Pasific, Tbk. Nilai maksimum menjelaskan bahwa jumlah komite audit independen pada perusahaan tersebut sebesar $66,67 \%$ dari seluruh jumlah komite audit.

Dari nilai rata-rata keseluruhan komite audit pada Tabel 4 dapat dilihat ada 3 perusahaan yang memiliki nilai komite audit $\mathrm{d} i$ atas rata-rata antara lain PT Kimia Farma (Persero), Tbk, PT Kalbe Farma, Tbk, PT Merck Indonesia, Tbk, sedangkan yang memiliki nilai di bawah rata-rata ada 2 perusahaan antara lain PT Indofarma, Tbk dan PT Tempo Scan Pasific, Tbk.

4) Gambaran Nilai Perusahaan Pada Perusahaan Sub Sektor Farmasi yang terdaftar di Bursa Efek Indonesia periode 2012-2016

Price to Book Value (PBV) pada Perusahaan Pada Perusahaan Sub Sektor Farmasi yang terdaftar di Bursa Efek Indonesia periode 20122016 sebagai berikut :

Tabel 5

Price to Book Value (PBV) pada Pada

Perusahaan Sub Sektor Farmasi yang

Terdaftar di Bursa Efek Indonesia Periode 2012-2016

\begin{tabular}{|c|c|c|c|c|c|c|c|}
\hline $\begin{array}{l}\text { Kode } \\
\text { Emiten }\end{array}$ & \begin{tabular}{|c|} 
Nama \\
Perusahaan
\end{tabular} & $\begin{array}{l}2012 \\
\text { (kali) }\end{array}$ & $\begin{array}{l}2013 \\
\text { (kali) }\end{array}$ & $\begin{array}{l}2014 \\
\text { (kali) }\end{array}$ & $\begin{array}{l}2015 \\
\text { (kali) }\end{array}$ & $\begin{array}{l}2016 \\
\text { (kali) }\end{array}$ & 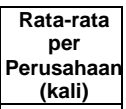 \\
\hline INAF & $\begin{array}{c}\text { PT } \\
\text { Indofarma, } \\
\text { Tbk } \\
\end{array}$ & 2,2899 & 1,2239 & 2,8312 & 0,8786 & 25,1945 & 6,4835 \\
\hline KAEF & $\begin{array}{c}\text { PT Kimia } \\
\text { Farma } \\
\text { (Persero), } \\
\text { Tbk }\end{array}$ & 2,8033 & 1,9996 & 4,3935 & 2,3526 & 6,6941 & 3,6486 \\
\hline KLBF & $\begin{array}{c}\text { PT Kalbe } \\
\text { Farma, Tbk }\end{array}$ & 6,8624 & 7,2654 & 9,1916 & 5,9257 & 5,9763 & 7,0442 \\
\hline MERK & $\begin{array}{c}\text { PT Merck } \\
\text { Indonesia, } \\
\text { Tbk } \\
\end{array}$ & 3,170 de & 8,2652 & 6,4729 & 6,4096 & 7,0736 & 7,2783 \\
\hline TSPC & $\begin{array}{c}\text { PT Tempo } \\
\text { Scan Pasific } \\
\text { Tbk }\end{array}$ & 4,9955 & 3,8743 & 3,2064 & 1,8721 & 1,9663 & 3,1829 \\
\hline \multicolumn{2}{|c|}{$\begin{array}{l}\text { Rata-rata per } \\
\text { tahun (kali) }\end{array}$} & $\begin{array}{l}5,02 \\
41\end{array}$ & $7, \frac{725}{7}$ & $\begin{array}{l}5_{1}, 219 \\
1\end{array}$ & $\begin{array}{l}3,487 \\
7\end{array}$ & 9,3810 & \\
\hline \multicolumn{7}{|c|}{ PBV Minimum } & $\begin{array}{c}0,8786 \\
251945\end{array}$ \\
\hline \multicolumn{7}{|c|}{ PBV Maksir } & 5,5275 \\
\hline
\end{tabular}

Berdasarkan Tabel 5 di atas, maka disajikan grafik PBV per tahun pada Perusahaan Sub Sektor Farmasi yang Terdaftar di Bursa Efek Indonesia Periode 2012-2016

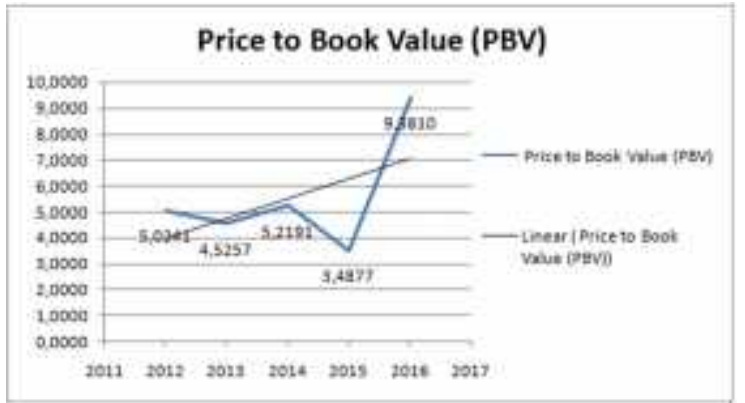

Sumber: Data Diolah

Grafik Rata-rata Price to Book Value (PBV) pada Perusahaan Sub Sektor Farmasi Periode 2012-2016

Berdasarkan Tabel 5 dan Gambar 4 di atas dilihat nilai rata-rata Price to Book Value (PBV) pada Perusahaan Sub Sektor Farmasi periode 2012-2016 berfluktuasi setiap tahunnya namun memiliki kecenderungan meningkat. Hal ini disebabkan harga per saham lebih besar dari nilai buku per saham. Nilai rata-rata PBV secara keseluruhan adalah sebesar 5,5275. Dari nilai rata-rata tersebut mengartikan bahwa jumlah harga saham yang ada dalam perusahaan sebesar 5,5275 kali dari nilai bukunya.

Selain itu dapat dilihat nilai minimum berada pada PT Indofarma, Tbk tahun 2015 sebesar 0,8786. Nilai minimum tersebut PT Indofarma, Tbk tahun 2015 sebesar 0,8786 kali dari nilai bukunya. Sedangkan nilai maksimum dari PBV sebesar 25,1945 berada pada PT Indofarma, Tbk tahun 2016. Nilai maksimum tersebut menjelaskan bahwa harga pasar saham pada PT Indofarma, Tbk tahun 2016 sebesar 25,1945 kali dari nilai bukunya.

Dari nilai rata-rata PBV keseluruhan pada Tabel 5, dapat dilihat ada 3 perusahaan yang memiliki PBV di atas rata-rata yaitu PT Indofarma, Tbk, PT Kalbe Farma, Tbk dan PT Merck Indonesia, Tbk, sedangkan yang memiliki nilai di bawah rata-rata ada 2 perusahaan yaitu PT Kimia Farma (Persero), Tbk dan PT Tempo Scan Pasific, Tbk.

\section{b. Analisis Deskrisptif Kuantitatif}

\section{1) Regresi Linier Berganda} penelitian ini menggunakan SPSS versi 21 dengan hasil yang terlihat pada Tabel 5 . menjelaskan bahwa harga pasar saham pada

Pengujian analisis regresi berganda pada 
Tabel 6

Hasil Analisis Regresi Linier Berganda Coefficients $^{a}$

\begin{tabular}{|c|c|c|c|c|}
\hline \multirow{2}{*}{\multicolumn{2}{|c|}{ Model }} & \multicolumn{2}{|c|}{$\begin{array}{l}\text { Unstandardized } \\
\text { Coefficients }\end{array}$} & \multirow{2}{*}{$\begin{array}{c}\begin{array}{c}\text { Standardized } \\
\text { Coefficients }\end{array} \\
\text { Beta }\end{array}$} \\
\hline & & B & $\begin{array}{l}\text { Std. } \\
\text { Error }\end{array}$ & \\
\hline \multirow{4}{*}{1} & (Constant) & 14,079 & 8,200 & \\
\hline & Kep_Inst & 8,077 & 7,609 & 209 \\
\hline & Dewan_KI & $-21,117$ & 13,123 & -,457 \\
\hline & Komite Audit & $-2,457$ & 6,032 &,- 116 \\
\hline
\end{tabular}

a Dependent Variable: PBV

Sumber: Hasil Pengolahan Data (SPSS 21.0), 2017

Berdasarkan Tabel 6, model persamaan regresi yang diperoleh adalah sebagai berikut: $\hat{Y}=14,079+8,077 X_{1}-21,117 X_{2}-2,457 X_{3}$

Artinya, tata kelola perusahaan dengan proksi kepemilikan institusional berpengaruh positif terhadap nilai perusahaan sedangkan dewan komisaris independen dan komite audit berpengaruh negatif terhadap nilai perusahaan pada Perusahaan Sub Sektor Farmasi yang terdaftar di Bursa Efek Indonesia periode 20122016.

\section{2) Koefisien Korelasi dan Determinasi}

Berikut hasil pengolahan data yang menunjukkan koefisien korelasi dan determinasi pada Tabel 7.

Tabel 7

Hasil Analisis Koefisien Korelasi dan Koefisien Determinasi Model Summary

\begin{tabular}{|c|c|c|c|c|}
\hline Model & $\mathrm{R}$ & R Square & $\begin{array}{l}\text { Adjusted R } \\
\text { Square }\end{array}$ & $\begin{array}{l}\text { Std. Error of the } \\
\text { Estimate }\end{array}$ \\
\hline 1 &, $437^{\mathrm{a}}$ & 191 &, 076 & 4,59719 \\
\hline \multicolumn{5}{|c|}{$\begin{array}{l}\text { a. Predictors: (Constant), Komite_Audit, Kep_Inst, Dewan_KI } \\
\text { b. Dependent Variable: PBV } \\
\text { Sumber: Hasil Pengolahan Data (SPSS 21.0), } \\
2017\end{array}$} \\
\hline
\end{tabular}

Berdasarkan Tabel 7 di atas terlihat bahwa koefisien korelasi $(r)$ adalah sebesar 0,437 yang berarti bahwa terdapat korelasi atau hubungan yang sedang antara variabel independen yaitu tata kelola perusahaan yang di proksikan dengan kepemilikan institusional, dewan komisaris independen dan komite audit dengan variabel dependen yaitu nilai perusahaan. Sementara koefisien determinasi $(R)$ adalah sebesar 0,191 yang berarti $19,1 \%$ tinggi rendahnya nilai perusahaan dapat dijelaskan oleh variabel tata kelola perusahaan pada Perusahaan Sub Sektor Farmasi, sisanya sebesar $80,9 \%$ dijelaskan oleh variabel lain yang tidak dimasukan dalam model penelitian ini misalnya kualitas audit, dewan direksi, kepemilikan manajerial dan faktor lain seperti faktor internal yang meliputi keputusan investasi, keputusan pendanaan, keputusan manajemen aset, dan faktor eksternal meliputi tingkat inflasi dan tingkat bunga yang mempengaruhi nilai perusahaan.
3) Uji Hipotesis

a) Uji Simultan (Uji F)

Hasil uji $F$ dalam penelitian ini dapat dilihat pada Tabel 8.

Tabel 8
Hasil Uji F
ANOVA $^{\mathrm{a}}$

Berdasarkan Tabel 8 di atas, hasil uji $\mathrm{F}$ diperoleh nilai $F_{\text {hitung }}$ sebesar 1,657 sedangkan $F_{\text {tabel }}$ dengan $(0,05 ; 3 ; 21)$ sebesar 3,07 atau dengan signifikansi $0,207>0,05$ maka $\mathrm{H}_{0}$ diterima, yang berarti bahwa tata kelola perusahaan berpengaruh tidak signifikan terhadap nilai perusahaan pada Perusahaan Sub Sektor Farmasi yang terdaftar di Bursa Efek Indonesia periode 2012-2016.

b) Uji Parsial (Uji t)

Hasil uji t dalam penelitian ini dapat dilihat pada Tabel 9 .

\begin{tabular}{|c|c|c|}
\hline & $\begin{array}{l}\text { Tabel } 9 \\
\text { Hasil Uji t } \\
\text { Coefficients }^{\mathrm{a}}\end{array}$ & \\
\hline Model & $T$ & Sig. \\
\hline $\begin{array}{ll} & \text { (Constant) } \\
1 & \text { Kep_Inst } \\
\text { Dewan_KI } \\
\text { Komite_Audit }\end{array}$ & \begin{tabular}{r|}
1,717 \\
1,062 \\
$-1,609$ \\
,- 407
\end{tabular} & $\begin{array}{l}, 101 \\
, 301 \\
, 123 \\
688\end{array}$ \\
\hline
\end{tabular}

Sumber: Hasil Pengolahan Data (SPSS 21.0),

$$
2017
$$

Berdasarkan Tabel 9 di atas, di atas dapat diketahui pengaruh masing-masing variabel independen terhadap variabel dependen sebagai berikut :

1) Kepemilikan institusional mempunyai nilai $t_{\text {hitung }}$ sebesar 1,062 sedangkan $t_{\text {tabel }}$ dengan $(0,05 ; 21)$ sebesar 2,07961, maka 1,062< 2,07961 atau dengan signifikasi 0,301 >0,05 maka $\mathrm{H}_{0}$ diterima, yang berarti bahwa kepemilikan institusional sebagai salah satu proksi tata kelola perusahaan berpengaruh tidak signifikan terhadap nilai perusahaan pada Perusahaan Sub Sektor Farmasi yang terdaftar di Bursa Efek Indonesia periode 2012-2016 secara parsial.

2) Dewan komisaris independen mempunyai nilai $t_{\text {hitung }}$ sebesar 1,609 sedangkan $t_{\text {tabel }}$ dengan $(0,05 ; 21)$ sebesar 2,07961, maka $1,609<2,07961$ atau dengan signifikasi $0,123>0,05$ maka $\mathrm{H}_{0}$ diterima, yang berarti 
bahwa dewan komisaris independen sebagai salah satu proksi tata kelola perusahaan berpengaruh tidak signifikan terhadap nilai perusahaan pada Perusahaan Sub Sektor Farmasi yang terdaftar di Bursa Efek Indonesia periode 2012-2016 secara parsial.

3) Komite audit mempunyai nilai $t_{\text {hitung }}$ sebesar 0,407 sedangkan $t_{\text {tabel }}$ dengan $(0,05 ; 21)$ sebesar 2,07961, maka 0,407<2,07961 atau dengan signifikansi $0,688>0,05$ maka $\mathrm{H}_{0}$ diterima, yang berarti bahwa komite audit sebagai salah satu proksi tata kelola perusahaan berpengaruh tidak signifikan terhadap nilai perusahaan pada Perusahaan Sub Sektor Farmasi yang terdaftar di Bursa Efek Indonesia periode 2012-2016 secara parsial.

\section{Evaluasi}

a. Evaluasi Tata Kelola Perusahaan pada Perusahaan Sub Sektor Farmasi yang Terdaftar di Bursa Efek Indonesia Periode 2012-2016

Dari hasil penelitian menunjukkan rata-rata kepemilikan institusional pada Perusahaan Sub Sektor Farmasi yang terdaftar di Bursa Efek Indonesia tahun 2012-2016 mengalami fluktuasi dan cenderung meningkat. Kepemilikan institusional minimum sebesar 0,0464 berada pada tahun 2015 pada PT Indofarma, Tbk.

Rata-rata dewan komisaris independen pada Perusahaan Sub Sektor Farmasi yang terdaftar di Bursa Efek Indonesia tahun 2012-2016 juga mengalami fluktuasi dengan kecenderungan menurun, dengan nilai minimum berada pada beberapa perusahaan yaitu PT Kalbe Farma, Tbk tahun 2012-2014, PT Merck Indonesia, Tbk tahun 2012-2016, dan PT Indofarma, Tbk tahun 2014-2016 yaitu sebesar 0,3333. Nilai dewan komisaris independen cenderung sama untuk beberapa perusahaan. Hal ini sesuai dengan peraturan yang telah ditetapkan OJK, jumlah wajib dewan komisaris independen sebesar $30 \%$ maka untuk perusahaan yang memiliki nilai diatas $30 \%$ pegawasan yang dilakukan menjadi kurang efektif, selain itu jumlah komisaris independen yang terlalu banyak akan mengeluarkan biaya pengawasan yang banyak juga. Menurut Hamdani (2016:31), monitoring cost adalah biaya yang timbul dan ditanggung oleh principal untuk memonitor perilaku agent, yaitu untuk mengukur, mengamati, dan mengontrol perilaku agent.

Sementara rata-rata komite audit pada Perusahaan Sub Sektor Farmasi yang terdaftar di Bursa Efek Indonesia tahun 2012-2016 memiliki kecenderungan menurun di setiap tahunnya dengan nilai minimum 0 , berada pada PT Tempo Scan Pasific, Tbk tahun 2013, 2014 dan 2016. Tidak adanya komite audit dalam perusahaan menyalahi aturan dari BAPEPAM dan menurunkan nilai perusahaan di mata investor. Jumlah komite audit independen lebih besar dari jumlah minimal yang ditentukan oleh BAPEPEM. Tetapi jumlah komite audit yang terlalu banyak akan menambah pengeluaraan untuk biaya pengawasan yang dampak akhirnya akan menurunkan harga saham.

b. Evaluasi Nilai Perusahaan pada Perusahaan Sub Sektor Farmasi yang Terdaftar di Bursa Efek Indonesia Periode 2012-2016

Dari hasil penelitian, ditunjukan kondisi nilai rata-rata perusahaan pada Perusahaan Sub Sektor Farmasi periode 2012-2016 yang diukur menggunakan PBV mengalami fluktuasi namun cenderung meningkat. Kondisi ini terlihat di mana nilai PBV minimum perusahaan berada pada PT Indofarma, Tbk tahun 2015 yaitu sebesar 0,8786, yang berarti bahwa harga pasar saham lebih rendah 0,8786 kali dibandingkan nilai bukunya. Price to Book Value (PBV) maksimum adalah sebesar 25,1945 terdapat pada PT Indofarma, Tbk tahun 2016 yang berarti harga sahamnya jauh lebih tinggi dari nilai bukunya. Rata-rata keseluruhan PBV adalah sebesar 5,5275 ini berarti ini berarti perbandingan harga saham terhadap nilai buku pada kondisi konstan.

Perusahaan yang tergolong dapat menciptakan nilai adalah perusahaan yang memiliki PBV lebih besar dari 1 (Hamdani, 2016:139). Dapat dilihat dari nilai minimum PBV lebih besar dari 1 maka dapat dinyatakan bahwa Perusahaan Sub Sektor Farmasi tergolong mampu menciptakan nilai perusahaan. Adapun PBV perusahaan pada tingkat minimum disebabkan harga saham yang rendah dibanding nilai bukunya. Harga saham yang mencerminkan nilai perusahaan bisa mengalami penurunan hingga tingkat terendah karna berbagai faktor yang mengakibatkan menurunnya minat investor untuk berinvestasi di perusahaan tersebut. Tinggi rendahnya harga saham menentukan nilai perusahaan di mata investor walaupun masih banyak faktor lain yang akan menjadi pertimbangan investor tetapi harga saham adalah cermin utama yang di pertimbangkan oleh para investor.

\section{c. Evaluasi Tata Kelola Perusahaan Terhadap Nilai Perusahaan pada Perusahaan Sub Sektor Farmasi yang Terdaftar di Bursa Efek Indonesia Periode 2012-2016}

Berdasarkan hasil penelitian, Tata kelola perusahaan berpengaruh tidak signifikan terhadap nilai perusahaan disebabkan oleh beberapa alasan yaitu Sub Sektor Perusahaan yang diteliti yang di dalamnya terdapat 
beberapa perusahaan yang dimiliki pemerintah sehingga independensi pengawasan yang dilakukan dapat di pengaruhi oleh faktor lain misalnya politik. Selain itu ukuran sampel yang kecil hanya 5 tahun saja sebagai periode penelitian, dan masih banyak faktor lainnya. Kepemilikan saham institusional perusahaan tetap menjaga tingkat pengawasan yang dilakukan terhadap manajeman akan berpeluang meningkatkan pertumbuhan dan nilai perusahaan.

\section{Kesimpulan Dan Saran}

1. Kesimpulan

a. Tata kelola perusahaan diukur dengan menggunakan indikator kepemilikan institusional, dewan komisaris independen dan komite audit. Kepemilikan institusional memiliki nilai rata-rata sebesar 0,1883 dengan nilai maksimum sebesar 0,395 dan nilai minimum sebesar 0,0464. Untuk rata-rata dewan komisaris independen sebesar 0,4150 dengan nilai maksimum sebesar 0,7500 dan minimum adalah sebesar 0,3333. Sedangkan rata-rata untuk komite audit sebesar 0,5333 dengan nilai maksimum sebesar 0,6667 dan nilai minimum sebesar 0 .

b. Rata-rata nilai perusahaan yang diukur dengan menggunakan Price to Book Value (PBV) sebesar 5,5275, dengan nilai PBV maksimum sebesar 25,1945 dan nilai minimum 0,8786 .

c. Dari hasil pengujian regresi linier berganda yang telah dilakukan, diperoleh persamaan regresi sebagai berikut $\hat{Y}=14,079+8,077$ $X_{1}-21,117 \quad X_{2}-2,457 \quad X_{3}$. Persamaan regresi tersebut menunjukan bahwa tata kelola perusahaan dengan proksi kepemilikan institusional berpengaruh positif sedangkan dewan komisaris independen dan komite audit berpengaruh negatif terhadap nilai perusahaan.

d. Berdasarkan pengujian koefisien korelasi dan determinasi diketahui bahwa nilai $r$ adalah 0,437 yang berarti bahwa terdapat korelasi atau hubungan yang sedang antara tata kelola perusahaan dengan nilai perusahaan. Sementara koefisien determinasi sebesar 0,191, hal ini berarti $19,1 \%$ variabel nilai perusahaan dapat dijelaskan oleh variabel tata kelola perusahaan pada Perusahaan Sub Sektor Farmasi, sisanya sebesar 80,9\% dijelaskan oleh variabel lain yang tidak dimasukan dalam model penelitian ini misalnya kualitas audit, dewan direksi, kepemilikan manajerial dan faktor lain yang mempengaruhi nilai perusahaan.

e. Hasil uji $F$ tabel diperoleh nilai $F_{\text {hitung }}$ sebesar 1,657 sedangkan $F_{\text {tabel }}$ sebesar 3,07 atau 1,657<3,07 dan nilai signifikansi 0,207 > 0,05 maka $\mathrm{H}_{0}$ diterima, yang berarti bahwa tata kelola perusahaan berpengaruh tidak signifikan terhadap nilai perusahaan.

f. Hasil pengujian uji t dengan derajat signifikan yang digunakan adalah 0,05, disimpulkan bahwa bahwa nilai $t$ hitung untuk kepemilikan institusional sebagai salah satu proksi tata kelola perusahaan mempunyai nilai thitung sebesar 1,062 sedangkan $t_{\text {tabel }}$ sebesar 2,07961 atau $1,062<2,07961$ dan nilai signifikansi 0,301 > 0,05 maka $\mathrm{H}_{0}$ diterima, yang berarti bahwa kepemilikan institusional berpengaruh tidak signifikan terhadap nilai perusahaan. Sedangkan t hitung untuk dewan komisaris independen mempunyai nilai $t_{\text {hitung sebesar }-1,609}$ sedangkan $t_{\text {tabel }}$ sebesar 2,07961 atau $-1,609>-2,07961$ dan nilai signifikansi 0,123>0,05 maka $\mathrm{H}_{0}$ diterima, yang berarti bahwa dewan komisaris independen berpengaruh tidak signifikan terhadap nilai perusahaan. Dan untuk komite audit mempunyai nilai $t_{\text {hitung }}$ sebesar $-0,407$ sedangkan $t_{\text {tabel }}$ sebesar 2,07961 atau $-0,407>-2,07961$ dan nilai signifikansi 0,688 >0,05 maka 
$\mathrm{H}_{0}$ diterima, yang berarti bahwa komite audit berpengaruh tidak signifikan terhadap nilai perusahaan. Berdasarkan nilai tersebut dapat disimpulkan bahwa $\mathrm{H}_{0}$ diterima atau dapat dikatakan terdapat pengaruh tidak signifikan antara tata kelola perusahaan terhadap nilai perusahaan secara parsial.

2. Saran

a. Berdasarkan hasil penelitian, menyatakan bahwa tata kelola perusahaan berpengaruh tidak signifikan terhadap nilai perusahaan, sehingga penting bagi perusahaan untuk tetap memperhatikan keberadaan dan kualitas tata kelola perusahaan yang baik untuk dapat memaksimalkan kinerja manajemen sehingga akan menaikkan nilai perusahaan dan memberikan nilai tambah bagi para stakeholder.

b. Berdasarkan hasil penelitian, menyatakan bahwa kepemilikan institusional berpengaruh positif terhadap nilai perusahaan, maka sebaiknya Perusahaan Sub Sektor Farmasi lebih banyak melepaskan saham untuk pihak ketiga kecuali untuk perusahaan milik pemerintah sehingga dapat meningkatkan tingkat pengawasan terhadap pihak manajemen yang akhirnya akan menaikan nilai perusahaan di mata investor.

c. Bagi Perusahaan Sub Sektor Farmasi jumlah anggota komite audit dan dewan komisaris independen sebaiknya dikurangi atau disesuaikan dengan kompleksitas perusahaan dengan tetap memperhatikan efektivitas dalam pengambilan keputusan serta bukan hanya fokus kepada jumlah komisaris independen dan komite audit tetapi tetap mempertahankan tingkat independensi dan profesionalisme dalam menjalankan tugas dan wewenangnya.

\section{E. DAFTAR PUSTAKA}

Astuti, Pratiwi Dwi. 2012. Akuntansi Keuangan Dasar 1. Yogyakarta : CAPS

Hamdani. 2016. Good Corporate Governance, Edisi Asli. Tangerang : Mitra Wacana Media.

Horne, James C. Van dan John $M$. Wachowiccz, Jr. 2012. Prinsip-prinsip Manajemen Keuangan, Edisi Ketigabelas, Jilid Satu. Jakarta: Salemba Empat.

http://www.ix.co.id/id-

id/beranda/perusahaantercatat/laporanke uangandan tahunan.aspx. diakses tahun 2017

Kasmir. 2010. Pengantar Manajemen Keuangan. Edisi Pertama. Cetakan Kesatu. Jakarta : Kencana.

Keown, J. et. al. 2004. Manajemen Keuangan : Prinsip-prinsip Dasar dan Aplikasi, Edisi Kesembilan, Jilid Satu. Jakarta : Indeks Kelompok Gramedia.

Muryati, Ni Nyoman Tri Sariri dan I Made Sadha Suardikha. 2014. Pengaruh Good Corporate Governance Terhadap Nilai Perusahaan. Bali. E-Jurnal Akuntansi Universitas Udayana, ISSN : 2302-8556.

Sutedi, Adrian. 2011. Good Corporate Governance. Jakarta : Sinar Grafika.

Sanda Ahmadu, Aminu S. Mikailu dan Tukur Garba. 2005. Corporate Governance Mechanisms and Firm Financial Performance in Nigeria. African Economic Research Consortium. ISBN 9966-944-66-4. 